\title{
Communal Space dengan Konsep Layer Building untuk Rancang Ulang Pasar Darmo Permai
}

\author{
Valentinus Yulindra Ganis dan Wahyu Setyawan \\ Departemen Arsitektur, Fakultas Teknik Sipil dan Perencanaan, Institut Teknologi Sepuluh Nopember (ITS) \\ e-mail: wahyu_s@arch.its.ac.id
}

\begin{abstract}
Abstrak-Ruang publik adalah salah satu elemen pendukung sebuah kawasan perkotaan yang dapat menawarkan sarana hiburan bagi masyarakat yang ada di dalamnya. Di kota Surabaya, kawasan Darmo Permai Timur yang merupakan kawasan perumahan terdapat pasar yang sudah berdiri sangat lama yaitu Pasar Tradisional Darmo Permai. Pasar ini muncul dengan tujuan menarik orang/ pembeli untuk membeli rumah dikawasan Darmo Permai pada tahun 1980an. Seiring berjalannya waktu, pasar ini mulai tidak relevan dan berubah menjadi pasar tumpah. Aktivitas tidak terkontrol, perubahan aktivitas pada pagi hari yaitu pasar dan malam hari menjadi warung makan, zoning pasar tidak teratur, sirkulasi menjadi tidak jelas, stan illegal dan lain - lain, di tambah dengan kurangnya ruang untuk aktivitas warga sekitar sehingga terjadinya minim interaksi sosial. Dengan pendekatan Community Based Development, mengajak warga sekitar sehingga menjadi ruang publik yang baru yang sesuai dengan kebutuhan mereka untuk memperbaiki lingkungan perumahan Darmo Permai
\end{abstract}

Kata Kunci-Pasar, Ruang Komunal, Ruang Publik.

\section{PENDAHULUAN}

$\mathrm{R}$ UANG publik memainkan peran vital dalam kehidupan sosial dan ekonomi masyarakat. Jenis ruang dan pertemuan ruang publik yang terletak di kota, menjadi sumber daya sosial yang penting. Terdapat 5 hal manfaat adanya ruang publik:

1. Pusat interaksi sosial

2. Memicu pembangunan ekonomi

3. Meningkatkan kualitas lingkungan sekitar

4. Perbaikan lingkungan

5. Peningkatan keterlibatan masyarakat

Untuk mendapatkan data/ permasalahan, digunakan metode dari buku How to Study Public Life karya Jan Gehl yaitu observasi dan wawancara [1].

Dengan metode ini, didapatkan permasalahan seperti kondisi sirkulasi pengunjung dan kendaraan yang buruk (Gambar 1), zona yang buruk antar pasar basah dan kering (Gambar 2), penghawaan dan pencahayaan alami yang kurang baik (Gambar 3), kebersihan lingkungan, perubahan aktivitas pasar pada pagi hari dan area makan malam hari, tidak sesuainya stan pasar dan kurangnya aktivitas untuk warga sekitar. Permalsahannya adalah bagaimana ruang public dapat diterima oleh lingkungan sekitar sehingga tidak menjadi benda asing. Uses\&Activities, Comfort\&Space, Sociability, Acces\&Linkage adalah prinsip ruang publik dari web pps.org [2]. Pengguna dan aktivitas menjadi fokus utama dalam desain dengan dukungan dari prinsip yang lainnya.

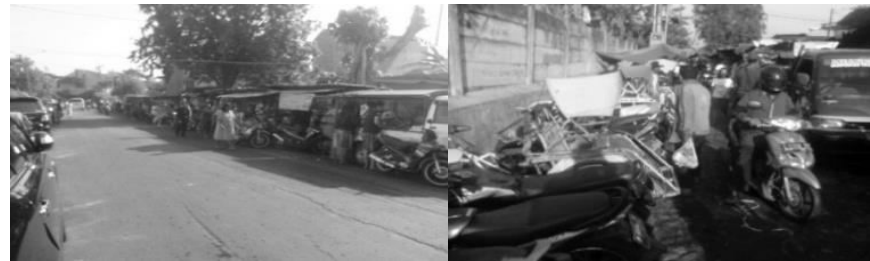

Gambar 1. Kondisi sirkulasi kendaraan dan pengunjung.

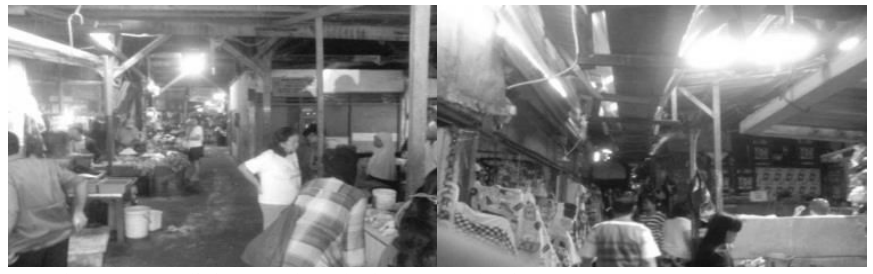

Gambar 2. Kondisi pasar basah dan pasar kering.

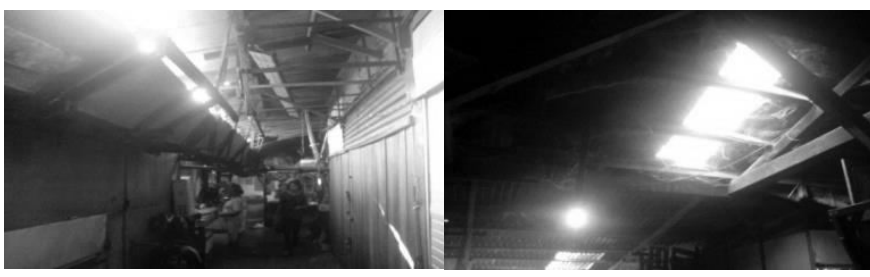

Gambar 3. Kondisi bagian dalam bangunan.

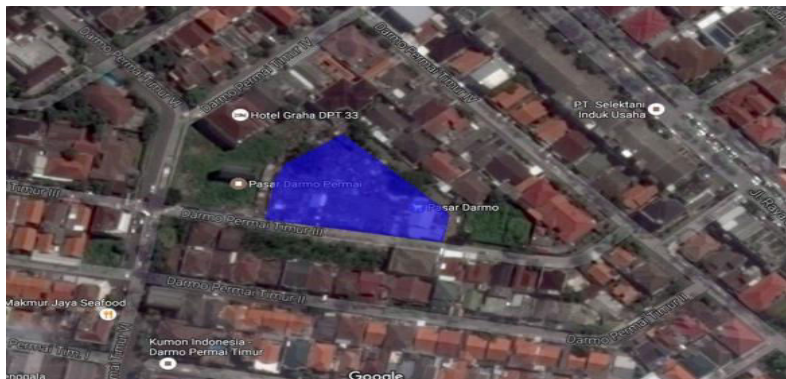

Gambar 4. Area Eksisting Pasar.

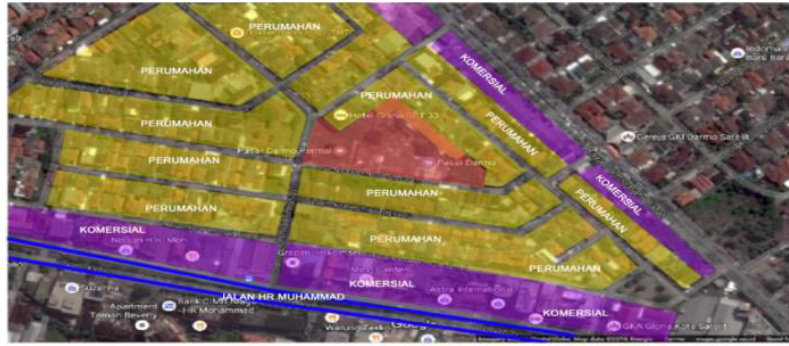

Gambar 5. Area Pasar yang Baru dan Zonasi Sekitar.

\section{A. Konteks}

Konteks yang dibawa dalam desain ini adalah konteks ruang publik yang terintegrasi dalam lingkungan perumahan 
dengan memperhatikan lingkungan sekitar. Kondisi eksisting sekarang adalah jalan perumahan dijadikan stan pasar. Untuk itu lahan yang dipilih, mengambil eksisting bangunan pasar ditambah dengan lahan kosong di sebelah kiri dan kanan bangunan. (Gambar 4 dan Gambar 5). Jan Gehl sendiri pernah mengatakan bahwa hal terpenting ketika ruang publik berada di area perumahan yaitu fisik dan sosial struktur di lingkungan tersebut. 2 hal ini dapat berinteraksi satu sama lain dan adanya dukungan dari warga sekitar. Hal yang krusial lainnya yaitu skala ruang, dimana dimensi atau ukuran antar ruang harus diperhatikan sebagai elemen penting sehingga pengunjung tidak berada di skala ruang yang gigantis [3].

\section{B. Gagasan Solusi dan Tujuan Desain.}

Rancang ulang menjadi jawaban atas permasalahan ini dengan memberikan value ruang publik sebagai ruang komunal untuk warga sekitar. Mempertahankan jumlah pedagang dan esensi pasar tradisional seperti jumlah eksisting pedagang, interaksi tawar menawar, sirkulasi tidak terlalu besar, penghawaan dan pencahayaan alami, dipertahankan dalam desain baru ini. Tujuan yang diharapkan dari desain ini yaitu tidak menjadikannya pasar tumpah, fleksibilitas ruang dengan aktivitas yang dibutuhkan, fleksibilitas program antara pasar dengan area makan.

\section{PROGRAM DESAIN}

\section{A. Deskripsi Tapak}

Metode analisa tapak Edward T. White menjadi salah satu tambahan metode tidak hanya untuk menganalisa tapak, melainkan membantumenemukan permasalahan yag ada di lahan itu sendiri. Poin - poin analisa tapak yang ada di buku Edward T. White sangat fleksibel sehingga tidak perlu memakai semua poin tersebut. Poin yang digunakan yaitu sirkulasi pejalan kaki dan kendaraan, zona peruntukan sekitar, iklim (matahari dan penghawaan), keramaian yang ditimbulkan bangunan itu sendiri [4].

Penambahan aktivitas baru menjadi pertimbangan sendiri dengan menanyakan secara langsung kepada warga mengenai aktivitas yang dibutuhkan.

\section{B. Program Ruang}

Daftar program ruang yang muncul dari kebutuhan kebutuhan setelah mewancarai warga dan pedagang pasar itu sendiri bisa dilihat di Tabel 1.

\section{PENDEKATAN DAN METODE DESAIN}

\section{A. Pendekatan Desain}

Pendekatan digunakan untuk menjawab isu yang dipaparkan yaitu Community Based Development. Pendekatan ini merupakan pendekatan dimana mengajak warga sekitar ikut dalam proses, mengenai masalah yang ada, kebutuhan akivitas dan menciptakan solusi [5]. Dalam pendekatan ini, ada hal yang diperhatikan yaitu level of engagement [6]. Level tersebut terdiri dari inform, consult, involve, collaborate empower. Dimana level ini mengatur seberapa dalam pendekatan. Penulis memilih level consult dengan pertimbangan waktu akademis. (Gambar 6)
Tabel 1.

Program ruang

\begin{tabular}{|c|c|c|c|c|c|c|}
\hline No & Ruang & Kapasitas & $\mathrm{P}(\mathrm{m})$ & $\mathrm{L}(\mathrm{m})$ & $\mathrm{T}(\mathrm{m})$ & Luas $\left(\mathrm{m}^{2}\right)$ \\
\hline 1 & Pasar Basah & 160 & 2.1 & 1.8 & 2.5 & 604.8 \\
\hline 2 & Pasar Kering & 40 & 3 & 3 & 2.5 & 360 \\
\hline 3 & Stan Makanan & 40 & 3 & 1.5 & 2.5 & 180 \\
\hline 4 & Area Makan & 150 & 2.1 & 2.1 & - & 661.5 \\
\hline 5 & Parkir Mobil & 75 & 5 & 2.5 & - & 937.5 \\
\hline 6 & Parkir Motor & 200 & 2 & 1 & - & 400 \\
\hline 7 & $\begin{array}{c}\text { Parkir Mobil Pick } \\
\text { Up }\end{array}$ & 10 & 5 & 3 & - & 150 \\
\hline 8 & Parkir Sepeda & 20 & 1.45 & 0.45 & - & 13.05 \\
\hline 9 & Parkir Becak & 15 & 2 & 0.9 & - & 27 \\
\hline 10 & $\begin{array}{c}\text { Area Futsal + } \\
\text { Basket }\end{array}$ & - & 25 & 18 & - & 450 \\
\hline 11 & Area bermain & 100 & - & - & - & 90 \\
\hline 12 & Plaza & 200 & - & - & - & 400 \\
\hline 13 & Plaza Air & 100 & - & - & - & 200 \\
\hline 14 & Janitor & 8 & 1.5 & 5 & 3 & 60 \\
\hline 15 & R. Keamanan & 8 & 3 & 1.5 & 3 & 72 \\
\hline 16 & Toilet Laki & 6 & 3.55 & 0.85 & 3 & 18.105 \\
\hline 17 & Toilet Perempuan & & & & & 16.065 \\
\hline 17 & Ruang Genset & 6 & 3.15 & 0.85 & 3 & 40 \\
\hline 18 & Musholla & $\begin{array}{c}10\left(2 \mathrm{~m}^{2} /\right. \\
\text { orang) }\end{array}$ & - & - & - & 20 \\
\hline 19 & Wudhu & $\begin{array}{c}10\left(1.5 \mathrm{~m}^{2} /\right. \\
\text { orang }\end{array}$ & - & - & - & 15 \\
\hline \multicolumn{6}{|c|}{ Total program ruang } & 4715.02 \\
\hline \multirow{2}{*}{\multicolumn{6}{|c|}{$\begin{array}{c}\text { Sirkulasi } 20 \% \text { dari total program ruang } \\
\text { Total luas yang dibutuhkan }\end{array}$}} & 934.004 \\
\hline & & & & & & $5130^{*}$ \\
\hline
\end{tabular}

\section{B. Metode Riset}

Dalam melakukan studi mengenai isu dan konteks yang dipilih, prinsip-prinsip mempelajari kehidupan publik digunakan. Prinsip-prinsip ini merupakan gambaran bagaimana cara mempelajari kegiatan manusia di luar ruangan, dengan melibatkan penghitungan, pemetaan, menjiplak / mencatat, melacak, meneliti jejak, fotografi, pembuatan jurnal, dan uji coba berjalan [1].

\section{Metode Berpikir}

Metode desain dapat dikategorikan pada beberapa tahapan proses. Proses pencarian masalah, dan proses pemecahan masalah dengan desain (Gambar 7). Terdiri dari tahap perencanaan, konseptual, pemrograman, dan desain. Dalam buku Problem Seeking, pada proses pengerjaan schematic program menuju schematic design, terdapat tahapan pengerjaan yang jelas dan fleksibel dengan patokan hasil nya berupa problem untuk nanti dikembangkan dalam tahap design development. Kelima tahapan itu adalah:
1. Establish goals
2. Collect and analyze facts
3. Uncover and test concepts
4. Determine needs
5. State the problem

Kelima tahap ini dapat dikerjakan sesuai dengan pendekatan yang dilakukan oleh perancang. Dengan mempertimbangkan isu public space dengan sub isu aktivitas yang diangkat dalam proposal tugas akhir ini, maka urutan yang sesuai adalah fact goal - need - concept - problem. Tahap fact adalah tahap awal yang digunakan untuk menentukan sebuah isu perancangan berdasarkan fakta yang ada di lapangan [7]. 


\section{Metode Perancangan}

Melihat pendekatan tersebut, metode yang digunakan adalah metode Bernard Tschumi mengenai program ruang. Dalam buku Architecture and Disjunction terdapat, metode program ruang yaitu cross programming [8]. Metode ini mencoba menumpuk aktivitas atau program A dengan program B berdasarkan waktu atau ada hal eksternal yang mempengaruhi.

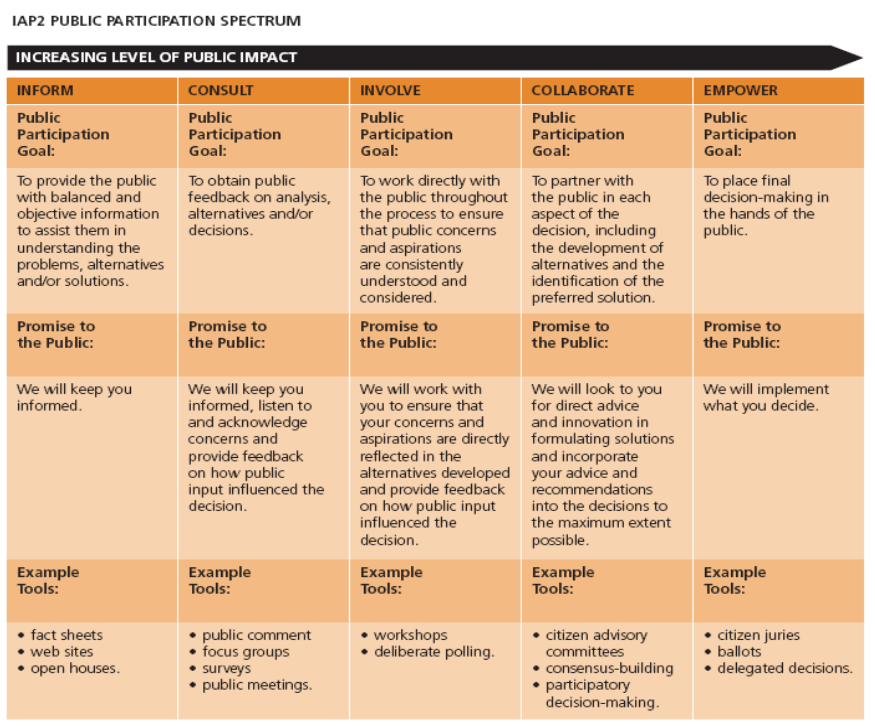

Gambar 6. Level of Engagement.

\begin{tabular}{|c|c|c|c|c|}
\hline Fakta & Goal & Kebutuhan & Konsep & Problem \\
\hline $\begin{array}{l}\text {-Perubahan } \\
\text { aktivitas } \\
\text { pagi hari dan } \\
\text { malam hari } \\
\text {-Bangunan } \\
\text { tidak mampu } \\
\text { menampung } \\
\text { jumlah } \\
\text { pedagang } \\
\text { sekarang } \\
\text {-Aktivitas } \\
\text { yang ada } \\
\text { memberikan } \\
\text { dampak } \\
\text { negatif } \\
\text {-Tidak } \\
\text { terorganisir } \\
\text { pasar basha } \\
\text { dan kering } \\
\text {-kondisi } \\
\text { bangunan } \\
\text { yang buruk } \\
\text { - } \\
\text { penghawaan } \\
\text { bangunan } \\
\text { tidak baik } \\
\text {-kurang } \\
\text { fasilitas } \\
\text { public untuk } \\
\text { warga } \\
\text { sekitar }\end{array}$ & $\begin{array}{l}\text { - } \\
\text { Redesain } \\
\text { pasar } \\
\text { darmo } \\
\text { permai } \\
\text { untuk } \\
\text { tidak } \\
\text { menjadi } \\
\text { kannya } \\
\text { pasar } \\
\text { tumpah } \\
\text { - } \\
\text { memberi } \\
\text { kan } \\
\text { ruang } \\
\text { yang } \\
\text { multifun } \\
\text { gsi untuk } \\
\text { warga } \\
\text { sekitar } \\
\text { dengan } \\
\text { memanf } \\
\text { aatkan } \\
\text { energi } \\
\text { alami } \\
\text { - } \\
\text { mencipta } \\
\text { kan } \\
\text { fleksibili } \\
\text { tas } \\
\text { fungsi } \\
\text { antara } \\
\text { pasar } \\
\text { dengan } \\
\text { area } \\
\text { makan }\end{array}$ & $\begin{array}{l}\text { 1. Ruang: } \\
\text {-Pasar } \\
\text { Tradisional } \\
\text {-Stan makanan } \\
\text {-Area Makan } \\
\text {-Area bermain } \\
\text {-futsal+basket } \\
\text { area } \\
\text {-plaza } \\
\text {-taman } \\
\text {-parkir mobil } \\
\text {-parkir motor } \\
\text {-kantor } \\
\text {-loading dock } \\
\text {-TPS } \\
\text {-Janitor } \\
\text {-Wudhu } \\
\text {-Musholla } \\
\text { 2. Kriteria } \\
\text { rancang } \\
\text {-Membentuk } \\
\text { ruang } \\
\text { multifungsi } \\
\text { dengan } \\
\text { menaungi ruang } \\
\text { dibawahnya } \\
\text {-membentuk } \\
\text { fleksibilitas pada } \\
\text { pasar dengan } \\
\text { area makan } \\
\text { berdasarkan } \\
\text { waktu } \\
\text {-bangunan } \\
\text { bersifat open air } \\
\text { untuk cross } \\
\text { ventilation } \\
\text {-meletakan TPS } \\
\text { jauh dari dari } \\
\text { aktivitas publik }\end{array}$ & $\begin{array}{l}\text { LAYE } \\
\mathrm{R} \\
\text { BUILD } \\
\text { ING } \\
\text {-Open } \\
\text { Air } \\
- \\
\text { Flexibi } \\
\text { lity } \\
\text { - } \\
\text { Shelter }\end{array}$ & $\begin{array}{l}\text { 1.Bagaima } \\
\text { na } \\
\text { menciptak } \\
\mathrm{n} \\
\text { multipurpo } \\
\text { se activity? } \\
2 . \\
\text { Bagaimana } \\
\text { merespon } \\
\text { fleksibilita } \\
\text { s pasar dan } \\
\text { warung? } \\
\text { 3. } \\
\text { Bagaimana } \\
\text { memberika } \\
\mathrm{n} \\
\text { kenyamana } \\
\mathrm{n} \\
\text { pengguna } \\
\text { energi } \\
\text { seminim } \\
\text { mungkin? } \\
4 . \\
\text { Bagaimana } \\
\text { cara } \\
\text { mengatur } \\
\text { loading } \\
\text { dock dan } \\
\text { parker } \\
\text { untuk } \\
\text { meminimal } \\
\text { isir } \\
\text { kemacetan }\end{array}$ \\
\hline
\end{tabular}

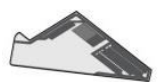

Penentuan sirkulasi parkir dan $\mathrm{BOH}$

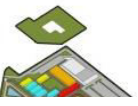

Memberikan green roof

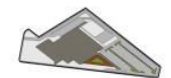

Peletakan zona pasar dan area makan

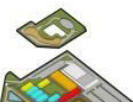

Konfigurasi ruang lantai 2

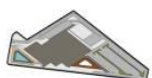

Peletakan plasa air untuk titik kumpul

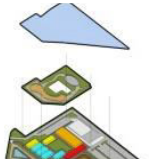

Pemberian atap sebagai naungan

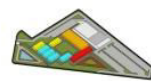

Penentuan zona pasar basah dan kering

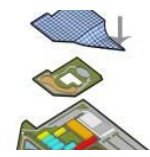

Penyesuaian ketinggian naungan

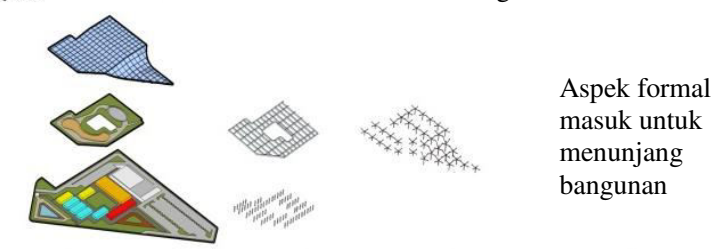

Gambar 8. Implementasi pada Desain
Stan Buah

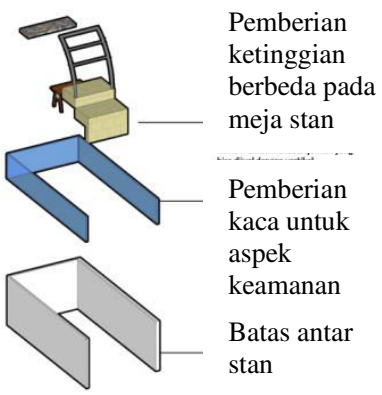

Pasar Kering

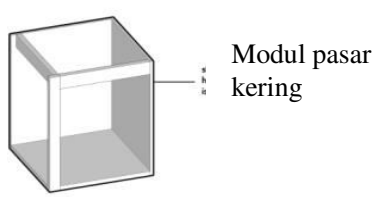

Stan makanan dan sayur

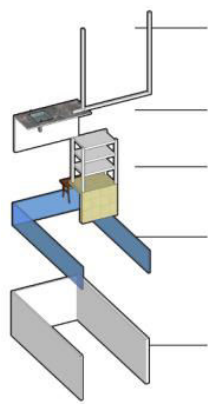

Tiang untuk stan makanan

Pemberian kaca untuk keamanan dan etalase untuk perubahan aktivitas

Batas antar stan
Stan Sayur

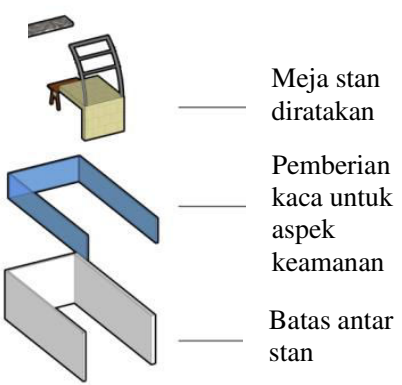

Stan Ayam

Meja untuk tempat
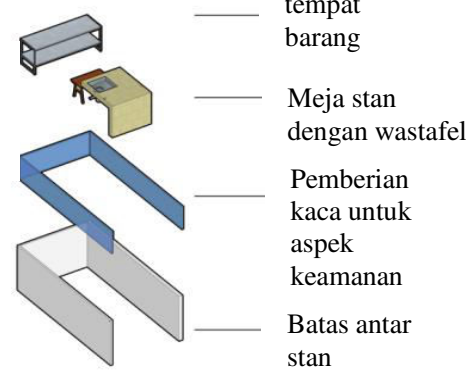

Stan Daging

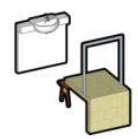

Meja stan diratakan

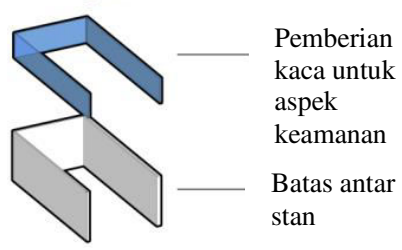

Gambar 9. Implementasi Konsep Stan 


\section{EKSPLORASI DAN HASIL RANCANG}

\section{A. Eksplorasi Formal}

Konsep yang diterapkan adalah Layer Building dengan konsep kecil open air, shelter, flexibility untuk menyelesaikan permasalahan yang ada. Konsep ini lebih menitik beratkan pemograman ruang sebagai awal untuk mendesain Akibat pemograman dan zona ruang yang menjadi fokus utama, bentuk bangunan menjadi paling terakhir untuk diselesaikan. (Gambar 8).

Penetapan letak ruang atau zonasi muncul dari beberapa faktor dimulai dari sirkulasi antar ruang parkir dan peletakan $\mathrm{BOH}$ (back of house), kedekatan antar program ruang, perubahan aktivitas pasar dan area makan, bau dari pasar untuk memisahkan zona pasar basah dan kering, ,pertimbangan peletakan ruang publik untuk warga, konfigurasi program pada ruang publik, dan pertimbangan memberikan naungan pada bangunan beserta struktur. Bangunan sendiri tidak masif, melainkan terbuka untuk mendapatkan penghawaan alami dan cahaya dari matahari ditambah pohon di sekitarnya sehingga lebih sejuk.

\section{B. Konsep Display Stan Pasar dan Stan Makan}

Pemograman terhadap cara menjual pada pasar ini perlu diperhatikan. Karena itu, stan dirancang sesuai dengan zonasi antar stan. Awal menentukan desain stan dengan melihat perilaku umum mengenai cara menjual, apa yang dilakukan di dalam stan, cara menata dagangannya, mengatur kebersihan. Dari situ, dibentuk model stan sesuai dengan zonasinya sehingga bisa mengakomodasi kebutuhan dari tiap zonasi pedagang pasar maupun untuk stan penjual makanan dimana terjadi perbedaan model antar tiap stan sesusai dengan apa yang di butuhkan (Gambar 9)

\section{Konsep Ruang Publik}

Cara yang digunakan untuk tidak membuat terjadinya tabrakan antara aktivitas pasar dengan ruang publik dengan meletakan di lantai 2 (diatas pasar). Karena meletakan ruang publik di lantai 2, perlu akses atau sirkulasi yaitu pemberian ramp (untuk difabilitas) dan tangga.

Awal mengkonfigurasikan ruang ini dengan menentukan aktivitas yang diperlukan, setelah itu menentukan ruang yang akan menjadi wadah untuk aktivitas tersebut. Setelah semua ruang terdefinisi, ruang tersebut digabung ke ruang lantai 2 sehingga terjadi tumpukan aktivitas yang memang dibiarkan begitu saja. Konsep yang dipilih yaitu bentukan cair / organik karena dengan membuat ruang publik menjadi tidak kaku, selain itu, ruang bisa dimaksimalkan lebih dari satu aktivitas dan mereduksi persepsi batas antar ruang (Gambar 10).

\section{Struktur dan Utilitas}

Konsep struktur terbagi 2, yang pertama yaitu struktur untuk menopang lantai 2 dan yang kedua yaitu menopang naungan bentang lebar. Untuk menopang lantai 2, menggunakan rangka kaku beton untuk vertikal maupun horizontal. Karena berada diatas area pasar, perlu penetapan bentang antar kolom sehingga tidak mengganggu ruang yang ada dibawahnya. Untuk naungan, menggunakan sistem struktur cabang dengan pipa baja untuk mengejar bentang lebar sehingga bisa mereduksi jumlah kolom mengingat ruang publik dan area makan perlu sedikit penghalang. (Gambar 11)

Sistem utilitas diletakan tidak berdekatan dengan ruang publik mengingat bangunan ini terbuka sehingga view dari dalam ke luar tidak boleh terganggu. Karena bangunan cenderung horizontal, dibutuhkan ruang yang cukup ekstensif untuk meletakan pipa di bagian bawah tanah, bawah lantai maupun di shaft. Setiap lantai diberi kamar mandi, tempat musholla dan wastafel di area makan. Distribusi berakhir di area yang membutuhkan air atau listrik. Untuk pasar dan area makan sendiri, yang terpenting adalah ketersediaan listrik, air pemadaman kebakaran, titik kumpul, air bersih dan air kotor pada unit dagang yang memerlukan wastafel. Untuk lantai 2 yang terpenting yaitu listrik, air bersih, air kotor, air untuk pemadaman kebakaran dan jalur evakuasi.

\section{KESIMPULAN}

Dalam tahapan perencanaan akan penanganan ruang publik dalam area perumahan, perlunya ada pendekatan secara langsung kepada warga sekitar dan penjual pasar sebagai eksisting pasar sehingga proses bagaimana mengetahui secara dalam apa yang dibutuhkan menjadi sangat penting untuk menjadikan awal rancangan. Sehingga desain pun tidak menjadi benda asing bagi warga sekitar melainkan sebagai ruang publik yang memfasilitasi secara sosial, ekonomi, maupun budaya dimana tidak adanya perbedaan secara kelas, melainkan sebagai katalisator untuk menengah kebawah dan menengah keatas.

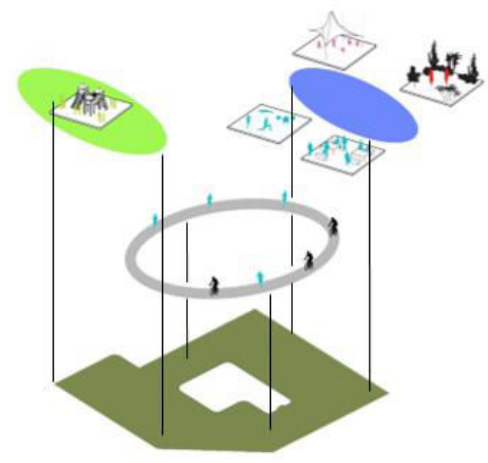

Gambar 10. Aksonometri penggabungan aktivitas.

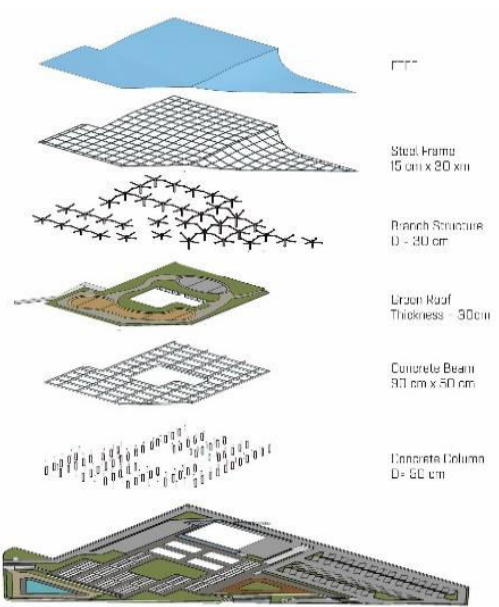

Gambar 11. Aksonometri Struktur 


\section{DAFTAR PUSTAKA}

[1] J. Gehl and B. Starve, How to Study Public Life, 1st ed. Washington DC: Island Press, 2013.

[2] Project for Public Spaces, "What Makes a Succesfull Place?," 2009. [Online]. Available: https://www.pps.org/reference/grplacefeat/.

[3] J. Gehl, Life Between Buildings. Washington DC: Island Press, 2011.

[4] E. T. White, Site Analysis: Diagramming Information for Architectural Design. Architectural Media Ltd, 1983.
[5] L. Luk, "What is Community Development," 2012. [Online]. Available: http://www.peernetbc.com/what-is-community-development.

[6] K. Pryosusilo, "A Model for Engagement," 2013. [Online]. Available: http://www.dse.vic.gov.au/effective-engagement/developing-anengagement-plan/a-model-for-engagement.

[7] W. M. Pena and et al, Problem Seeking - an Architectural Programming Primer. New York: John Wiley \& Sons Inc, 2001.

[8] B. Tschumi, Architecture and Disjunction. England: MIT Press, 1996. 